An International Journal of Optimization and Control: Theories \& Applications

ISSN: 2146-0957 eISSN: 2146-5703

Vol.9, No.3, pp.6-14 (2019)

https://doi.org/10.11121/ijocta.01.2019.00762

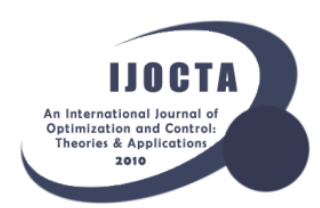

RESEARCH ARTICLE

\title{
Investment evaluation of wind turbine relocation
}

\author{
Hasan Huseyin Yildirim ${ }^{a *(D)}$, Sakir Sakarya ${ }^{b}$ (D) \\ ${ }^{a}$ Department of Banking and Finance, Balikesir University, Turkey \\ ${ }^{b}$ Department of Economics and Administrative Sciences, Balikesir University, Turkey \\ hhyildirim@balikesir.edu.tr, sakarya@balikesir.edu.tr
}

\section{ARTICLE INFO}

Article history:

Received: 18 December 2018

Accepted: 11 February 2019

Available Online: 19 March 2019

Keywords:

Energy

Wind energy

Energy investment valuation

Energy investment decisions

AMS Classification 2010:

OOA69, 91G50, 37N40

\begin{abstract}
Energy has become one of the most important building blocks of many changes in the world, and it still maintains this quality. The demand for natural resources and energy continues to increase daily. For this reason, the supply of reliable and sustainable energy has become an important issue that concerns and occupies mankind. Of the renewable energy sources, wind energy is a clean, reliable and inexhaustible source of energy with low operating costs. Turkey is a rich nation in terms of wind energy potential. In this context, the profitability of investments made in utilising domestic and renewable energy potential is important. Investment efficiency is a very important issue before and during the investment period due to the fact that wind energy investments are high cost investments. In this study, a solution will be proposed for the replacement of inefficient wind turbines which have been installed. In the ideal solution of the issue, the remaining lifetime of the wind turbine which is to be replaced and capacity utilization at the new location of the turbine will be used as key input factors. The results showed that it was important for the relocation decision to be made early for the investment to be more profitable. In the event of delayed decisions to relocate the turbine, a high capacity factor is expected in the new location. If a high capacity factor is not achieved, the relocation of the turbine will be meaningless and losses will be incurred for the investor. Also according to the results of the analysis, in the first two years, the turbine operating at a low capacity of $19 \%$ and $17 \%$ is profitable if it works at $26 \%$ capacity until the end of its economic life when change is made in the third year.
\end{abstract}

\section{Introduction}

Countries aiming for sustainability in economic growth and development ensure the reliability of energy supplies. For countries to provide their energy needs uninterruptedly, it is important for domestic and renewable energy sources to be utilised. In Turkey, which is one of the developing countries, the economic change experienced in recent years has led to a rapid increase in demand in the energy sector, as it has in other sectors. While electricity production in Turkey showed an average annual increase of $3.6 \%$ between the years 1970 and 2000, electricity production increased annually by $8.9 \%$ on average between the years 2000 and 2017. In this regard, Turkey was one of the OECD countries in which energy demand increased the most rapidly. Electricity production in Turkey in 2017 increased by $5.6 \%$ to 294.8 GWh compared with the previous year. $37 \%$ of this production was obtained from natural gas, $33 \%$ was obtained from coal, $20 \%$ from hydraulic energy, $6 \%$ from wind energy, $2 \%$ from geothermal energy and $2 \%$ from other sources [1]. In 2017 , approximately $70 \%$ of electricity production came from fossil sources, namely coal, liquid fuels and natural gas, while about $28 \%$ was obtained from renewable energy sources. When evaluating Turkey's 2017 energy situation, the high rate of energy use from fossil sources leads to environmental problems such as greenhouse gas emissions. Furthermore, the fact that a high percentage of the required energy is provided by imports has a negative effect on the balance of payments in a national economic sense. Between the years 1996 and 2017, energy imports made up an average of $20 \%$ of total annual imports. In 2017, total imports amounted to 234,156 million US dollars, $16 \%$ of which consisted of energy imports of 37,194 million US dollars. The 2015 foreign trade deficit was 76,736 million US dollars. If Turkey's energy needs were 
obtained from domestic sources instead of imported sources, the foreign trade deficit would be reduced by approximately $48 \%$. Considering the overall picture of energy in Turkey in recent years, providing the required energy from domestic and renewable sources has become essential.

With regard to renewable energy potential, Turkey is a country with high potential for obtaining electricity production from wind and solar energy. According to the criteria specified, wind potential at a height of 50 metres on Turkey's wind atlas ranges from good to excellent, approaching 48 GW [2]. By July 2018, Turkey's wind-based energy capacity had reached 7 GW [3]. Turkey's wind-based power is about $15 \%$ of the energy potential that can be obtained from wind.

In meeting increasing energy needs, energy sources that reduce dependence on foreign sources and cause fewer environmental problems should be used within the energy portfolio. For these reasons, increasing domestic and renewable energy sources is essential for Turkey, and this will also provide many benefits for the national economy. Within the scope of the 2015-2019 Strategic Plan prepared by the Ministry of Energy and Natural Resources, based on the diversification of resources in energy consumption with continuous, sustainable, environmentally friendly, good quality, reliable and low-cost energy for final consumers, the greatest possible utilisation of domestic and renewable energy sources was included among the main aims. Accordingly, the 2015-2019 Strategic Plan consists of 8 themes, 16 aims and 62 targets. In the 2015-2019 Strategic Plan, in the area of Energy and Natural Resources, common development needs such as good governance and stakeholder interaction, regional and international activity, technological research, development and innovation, and improvement of the investment environment are emphasised, while in the Energy field, security of supply and energy efficiency and saving are given priority. Moreover, in the field of Natural Resources, the subjects of security of supply of raw materials and efficient and effective use of raw materials are given attention. The subject of sustainability, which is regarded as an indispensable approach in the process of acquiring energy and natural resources for the economy and of their consumption, is designed not as a separate theme, but as a framework which covers all the themes [4].

As can be seen in the 2015-2019 Strategic Plan prepared by the Ministry of Energy and Natural Resources, sustainability as a framework is aimed for and a Turkey that benefits from domestic and renewable natural resources is targeted by diversification of energy sources to ensure security of supply. The use of domestic and renewable energy sources ensures diversification of resources within the energy portfolio, thereby allowing important progress to be made in reducing dependence on foreign energy sources and developing an environment that provides security of energy supply [5]. When considering why domestic and renewable energy is needed and why the prepared strategic targets are frequently deliberated, the importance of financial support for investments in renewable energy sources is stressed.

The increase in wind energy investments in Turkey and the world is striking. Is the main reason for this increase the fact that wind energy is an alternative energy source for meeting the needed and ever-increasing demand for energy? Or is it the fact that investments in wind energy are economically profitable? The answer to both questions explains the interest that there is in investment in wind power plants (WPP).

Before wind energy investments are begun, two basic analyses need to be made. The first of these is the technical analysis, which includes technical components such as the place where the investment is to be made, the investment capacity, the choice of turbines to be used in the investment, etc. The second analysis to be made is the financial analysis of the investment, which determines whether the investment is economically profitable or not. In both the technical and the financial analyses, there are a number of uncertain variables which affect the investment.

In evaluating a wind energy project in an economic sense, a project estimate of the installation costs must be made. In the technical evaluation of a WPP investment, the subjects in which there is insufficient knowledge and uncertainties regarding the WPP investment are factors such as when it will be completed, when the installation of the investment will begin, when the installation period of the investment will be completed, future changes in prices of materials to be used in the investment and how long the supply of the turbine from the manufacturer will take. Businesses have to make decisions under the existence of uncertainties like these. It is important for companies to make decisions that are as correct as possible and that will gain the most profit.

In this study, alternatives are discussed related to the relocation of 8 wind turbines for which adequate wind measurements had not been made in the technical analysis of WPP investments and which had been installed in unproductive locations. In the relocation of the 8 wind turbines that had been installed in unproductive locations and were operating at low capacity, the minimum required capacity of the new location was determined. Moreover, the capacity of the new location created for a return to profitability was determined separately for each year up to the end of the economic life of the turbine. In this way, it was revealed in which year and at what capacity a turbine that had been installed in the wrong place could be turned into a profitable investment in its new place of installation.

\section{Literature review}

Despite the increasing interest in renewable energy technologies, following the literature review conducted, it was observed that few studies have been conducted regarding economic assessment of investments in this field. Some of the studies that 
evaluate WPP investments in an economic sense are included below. It is considered that this study will also contribute to the literature.

In a study by Desrochers and Blanchard [6] to examine the cost effectiveness of wind energy, one year's hourly data for wind turbines were utilised. In their study, with the aid of the model established, the energy production capacities of different types of wind turbines were compared by means of simulation. It was concluded that the lower the investment constraints and the higher the production, the higher the rate of wind energy that could be absorbed by the system. With the system they developed, the inputs of different wind turbines into the system in terms of energy and capacity can be calculated [6].

In a study carried out by Venetsanos et al. [7], the net present value (NPV) and real options (RO) methods were used to evaluate wind energy for Greece, a country which has high potential in terms of renewable energy. It was determined that since investments in wind power plants involved high uncertainties, it would be beneficial to use the RO method as a complement to the NPV method [7].

In his study conducted in 239 locations selected from different states of the USA, using Monte Carlo simulation, Liberman [8] examined the payback periods of WPP investments for the locations depending on meteorolgical wind data. Due to the different prevailing wind speeds of the locations, the payback periods for the investments to be made in the locations were different. In areas with high wind speeds, the payback periods for the wind energy investments were shorter than in areas with low wind speeds [8].

In their study, Özerdem et al. [9] calculated the technical and economic feasibility of investments in wind power plants for the Izmir region in Turkey. For the technical feasibility study, wind speed, prevailing wind direction and temperature data were utilized. For the economic feasibility study, three different scenario groups for investment were examined with regard to net present value (NPV), internal rate of return (IRR) and payback period (PBP). The study revealed that the cost of the installed capacity per $\mathrm{kWh}$ had different characteristics as a function of capacity. It was concluded that the larger the capacity, the smaller the cost per $\mathrm{kWh}$. It was also determined that investments with high installed capacity had high IRR [9].

In the study by Vardar and Çetin [10], the unit kWh energy cost generated by wind energy in 14 selected locations in Turkey was calculated. To calculate the unit $\mathrm{kWh}$ energy production cost, data and power curves for three turbines selected from the regions were utilized. The results revealed that the most advantageous and economic location was Bozcaada [10].

Moran and Sherrington [11] calculated the contribution to the local area of investment in a wind power plant in Scotland by examining the positive and negative factors through NPV analysis. It was revealed that despite all the expenditure, a wind power plant created a net increase in welfare [11].

Madlaner and Wenk (2008) investigated the installed energy capacity of Switzerland and compared the NPVs of the energy sources with Monte Carlo simulation (MCS). By utilizing the outputs obtained with the MCS analysis, the optimum energy portfolio created from the types of energy sources in certain proportions was calculated [12].

In their study, Williams et al. [13] simulated the benefits to be obtained from investment in and operation of wind power plants for two different regions in Northern Arizona. An attempt was made to estimate the uncertainties related to the investment with the MCS applied. In this way, an attempt was made to determine the benefits to be obtained from economic activity during and after the WPP investment period for the economy of both regions [13].

In a study conducted by Vardar and Çetin [14], the unit $\mathrm{kWh}$ cost generated from wind energy in 22 selected locations in Turkey was calculated. To calculate the unit $\mathrm{kWh}$ energy production cost, data and power curves for three turbines selected from the regions were utilized. The results revealed that the most advantageous and economic location was Kumköy [14].

Ay [15] attempted to determine in what ways different financing choices affected the results of wind energy investments. In the study, economic evaluations were made in two different situations, namely one that took account of depreciation and one that did not. The economic evaluation results were different for the two different situations. When depreciation was taken into account in the economic evaluation, cash flows were higher. Therefore, it was concluded that depreciation is an important factor that needs to be taken into account in economic evaluation of investments [15].

In Hamamcioğlu's study [16], the wind energy potential of the region was determined by using data obtained from a wind measurement station installed on the Campus of Yildız Technical University. Next, the annual amount of energy that would be produced by two wind turbines with different capacities was calculated with the WAsP program. In two different scenarios, the unit electricity cost that would be obtained was analyzed with economic evaluation criteria like payback period and internal rate of return methods. The analysis results revealed that investment made in accordance with the two scenarios would yield profits [16].

In their study, Frølunde and Obling [17] conducted an economic evaluation of WPP investments by comparing discounted cash flows (DCF) and real options valuation (ROV) approaches. In the economic evaluation of WPP investments, it was concluded that both methods were successful and usable methods [17].

Cardell and Anderson [18] simulated power generation costs at different wind speeds. In the scenarios created 
for the study, it was determined that domestic wind generation was correlated with wind speed [18].

In the study conducted by RehmAn et al. [19], an economic evaluation of a $20-\mathrm{MW}$ wind power plant investment in the eastern region of Saudi Arabia was carried out. According to the technical assessments conducted, the planned location of the wind power plant investment had a $33.7 \%$ capacity. When all the input costs affecting the investment were considered, the production cost of the investment per $\mathrm{kWh}$ was calculated as \$2.94. It was concluded that in the area to be measured and thereabouts, a wind power plant investment could be developed [19].

By establishing a model based on uncertain environmental factors for a 13-GW WPP investment to be set up in Turkey, Ertürk [20] calculated the NPV of the investment. Considering the tariffs in the Renewable Energy Law of 2005 in Turkey, it was concluded that provided the wind speed in the location of the WPP investment was $7.5 \mathrm{~m} / \mathrm{s}$ and over, the investment could be economically profitable [20].

Using RETScreen analysis software, Doğan et al. [21] performed a cost analysis for 3 wind power plants with 1-MW, 5-MW and 10-MW power levels in Hatay province. As a result, it was concluded that in an economic sense, wind power plant investments with a capacity of at least $2 \mathrm{MV}$ and above should be preferred based on bank interest income [21].

Using the MCS method for the economic evaluation of WPP investments, Khindanova [22] obtained the distribution of the net present value (NPV), which is an output variable, by modelling the stochastic variables of electricity price and cost uncertainties. The NPV distribution obtained gives the wind power plant investor the opportunity for a deeper assessment when compared with a single point estimate of NPV or different scenario outputs. The method employed allows the wind power plant investor to acquire knowledge about risk measurements such as standard deviation, skewness, kurtosis and extreme NPV values that may be created [22].

Özçelik [23] examined the investment profitability of 4 locations in Turkey by considering cash flows that affect wind energy investments. Using the NPV and IRR methods of project evaluation, it was determined that of the locations examined, investments made in Karaburun (Izmir) and Samandağ (Hatay) would be profitable [23].

\section{Research method}

To evaluate the suitability of an investment project, all the expenditure and income of the project must be taken into account. To determine the economic suitability of wind energy investments, feasibility studies of the economic factors must first be carried out at the financial analysis stage. For a WPP investment to be made, it must first be placed in a competitive position with other alternative projects. A feasible WPP investment must be profitable for the producer and provide cheaper energy for the consumer compared to other energy sources.

In economic analyses carried out for WPP projects, payback period, project profitability and productvity, and net present value obtained throughout economic life are calculated [24].

In this study, alternatives related to the relocation of 8 wind turbines are discussed, as shown in Figure 1. For this aim, analyses of a WPP investment that maintains its activity in Balıkesir province in the Southern Marmara region have been made by utilizing actual data. The data for eight $3 \mathrm{MW}$ wind turbines in the installed plants of the wind power company have been used in the study. The 8 turbines selected are turbines that function in the same WPP area and have been relocated because they were low capacity. One of the codes of the turbines analyzed is identified as WTG34, as seen in Figure 1.

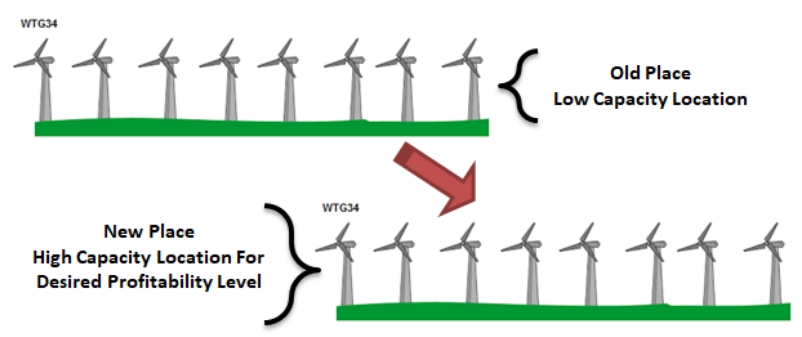

Figure 1. Relocation of wind turbines

In the case of relocation of the 8 wind turbines installed in unproductive locations and operating at low capacity, the minimum capacity required at the new location was determined.

In the implementation section of the study, the payback period method, which is a test of economic profitability of a WPP investment, was used. There are two different types of calculation in the payback period method. The first of these is the method that does not take the time value of money into account (Eq. (1)). With this method, the year in which the cash inflows and cash outflows of the investment are equalized is calculated without accounting for the discount factor (resource cost of the investment) [25].

$$
\sum_{\mathrm{t}=0}^{\mathrm{n}} \mathrm{R}_{\mathrm{i}}=\sum_{\mathrm{t}=0}^{\mathrm{n}} \mathrm{C}_{\mathrm{i}}
$$

The second method, however, takes the time value of money into account (Eq. (2)). With this method, the year in which the cash inflows and cash outflows of the investment are equalized is calculated after discounting [26].

$$
\sum_{t=0}^{\mathrm{n}} \frac{\mathrm{R}_{\mathrm{i}}}{(1+\mathrm{k})^{\mathrm{t}}}=\sum_{\mathrm{t}=0}^{\mathrm{n}} \frac{\mathrm{C}_{\mathrm{i}}}{(1+\mathrm{k})^{\mathrm{t}}}
$$

In both methods, the sooner the payback period is realized during the economic life of the investment, the better it is for investment profitability and performance. The economic position of a wind turbine basically depends on the electrical energy it generates. The most 
basic and important input in electricity production is wind speed. Eq. (3) shows the equation for production output obtained from wind power [27].

$$
\text { Power }=\mathrm{kC}_{\mathrm{p}} 1 / 2 \rho \mathrm{AV}^{3}
$$

$\mathrm{P}=$ Power output, kilowatts

$\mathrm{Cp}=$ Maximum power coefficient, ranging from 0.25

to 0.45 , dimension less (theoretical maximum $=0.59$ )

$\rho=$ Air density, $\mathrm{lb} / \mathrm{ft} 3$

$\mathrm{A}=$ Rotor swept area, $\mathrm{ft} 2$ or $\pi \mathrm{D} 2 / 4$ (D is the rotor

diameter in $\mathrm{ft}, \pi=3.1416$ )

$\mathrm{V}=$ Wind speed, $\mathrm{mph}$

$\mathrm{k}=0.000133$ A constant to yield power in kilowatts.

(Multiplying the above kilowatt answer by 1.340

converts it to horse- power [i.e., $1 \mathrm{~kW}=1.340$

horsepower]).

Wind power is proportional to the cube of wind speed. To explain this with an example, when the wind speed at a location is doubled, energy production increases 8 times. Therefore, the wind speed in the place where the turbine is installed is the most important factor affecting electricity generation, and this situation also reduces the cost associated with electricity generation. This situation also ultimately reduces the payback period of the investment.

$$
\mathrm{C}_{\mathrm{E}}=\frac{\mathrm{C}_{\mathrm{A}}}{8760 \mathrm{C}_{\mathrm{F}} \mathrm{P}_{\mathrm{R}}}
$$

In Equation 4, the cost per unit $\mathrm{kWh}$, " $\mathrm{C}_{\mathrm{E}}$ ", is a good economic indicator. In using electricity generation dependent on wind to determine cost, the characteristics of the wind regime are an important factor. " $\mathrm{C}_{\mathrm{F}}$ " expresses the capacity factor, " $\mathrm{C}_{\mathrm{A}}$ " denotes the annual operating cost, and " $\mathrm{P}_{\mathrm{R}}$ " represents the designed power of the turbine.

Figure 2 shows the relationship between wind speed and power production. Power production begins at wind speeds of 3-4 m/s and stops at $25 \mathrm{~m} / \mathrm{s}$ according to turbine scale and type.

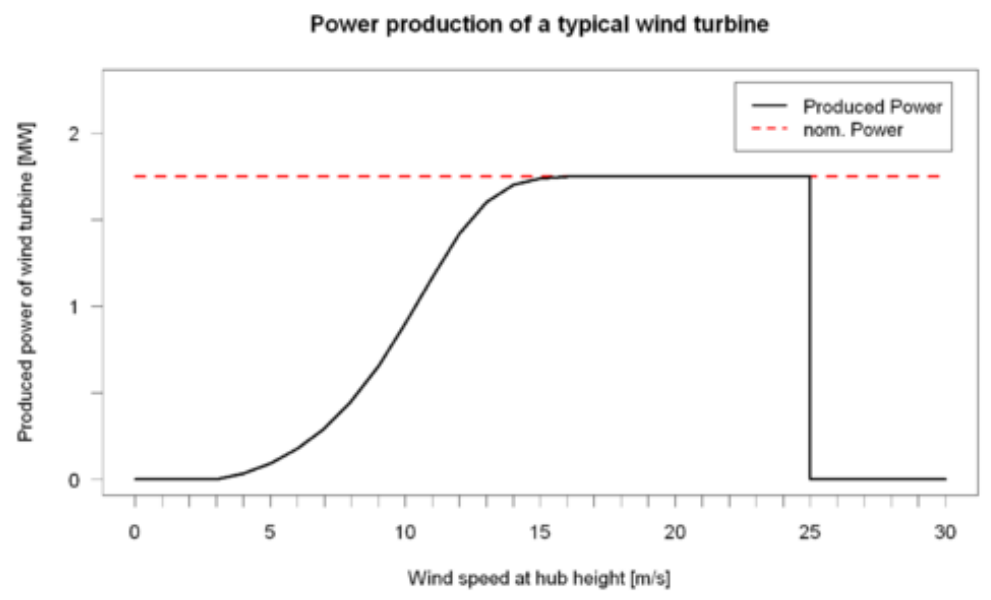

Figure 2. Power curve for wind speed and power production.

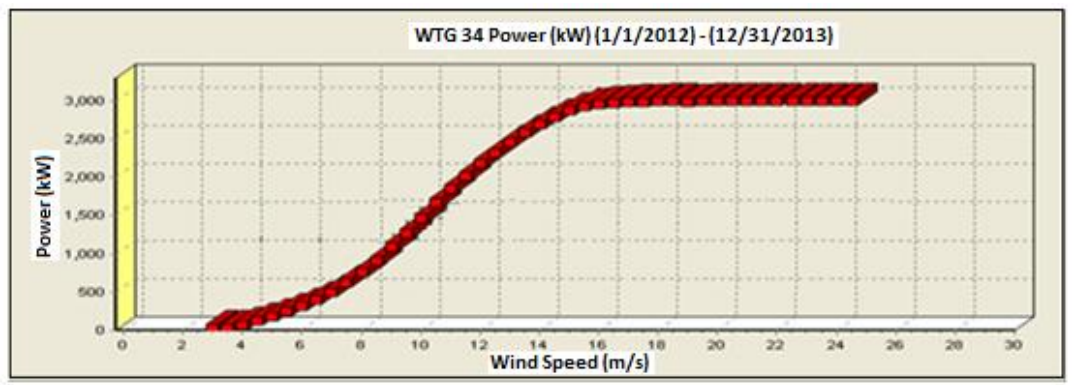

Figure 3. WTG34 power curve.

\subsection{Input parameters for the research}

The average capacity use of the 8 wind turbines that were relocated during the WPP investment was $18 \%$. The wind turbine coded WTG34 is one of the 8 wind turbines that were relocated during the WPP investment. Considering electricity generation compared with the other wind turbines, the electricity generation of wind turbine WTG34 is a turbine showing the average performance of the 8 turbines for 
the previous 2 years. Figure 3 shows the power curve for wind turbine WTG34. The power curve for wind turbine WTG34 was obtained by using the realized wind speeds and the power production values at frequencies of ten-minute periods between the dates 01.01.2012 and 31.12.2013.

In Figure 3, the horizontal axis of the power curve for wind turbine WTG34 shows wind speed in $\mathrm{m} / \mathrm{s}$, while the vertical axis shows power in $\mathrm{kW}$. When the wind speed of wind turbine WTG34 reached approximately $2.3 \mathrm{~m} / \mathrm{s}$, production commenced, and when the wind speed reached about $16.6 \mathrm{~m} / \mathrm{s}$, production reached full capacity, while at a wind speed of $25 \mathrm{~m} / \mathrm{s}$, the turbine stopped generating.

\subsection{Inputs for economic analysis of the turbines}

The input variables defined as assumptions to be used in the WPP project are the same for each turbine and are shown in Table 1. The parameters used in wind energy production have been created using sources in the literature [28].

In Table 1, the input variables defined as assumptions for wind turbine WTG34 are grouped under four headings, namely production parameters, operating expenses, investment expenditure and financial variables.

One of the production parameters for wind turbine WTG34 is individual unit capacity, and the individual unit capacity of the turbine is $3 \mathrm{MW}$. Another input is electricity selling price, and this was set as 7.3 US cents per $\mathrm{kWh}$ as a guarantee of purchase for wind power plants by YEKDEM ("Yenilenebilir Enerji Kaynakları Destekleme Mekanizması", or Support Mechanism for Renewable Energy Sources). As well as electricity purchase price, incentives for unit electicity sales by the use of domestic components in WPP investments are also included. When domestic components are used in WPP investment, incentives are provided as follows: 1.3 US cents per $\mathrm{kWh}$ for use of domestic rotors and nacelles, 1 US cent per $\mathrm{kWh}$ for use of domestic generators, $0.8 \mathrm{US}$ cents per $\mathrm{kWh}$ for use of domestic turbines, and $0.6 \mathrm{US}$ cents per $\mathrm{kWh}$ for use of domestic turbine towers.

In the second group of input variables for wind turbine WTG34, operating expenses are included. In operating expenses, annual maintenance expenditure per unit was determined as $\$ 37,000$. The number of staff employed in a WPP investment was assumed to be one person for 4 turbines on average. The average monthly cost of each employee was specified as \$1,200. As activity costs of the operation, in WPP investments $\$ 35,000$ in system usage costs per unit is paid annually to the public, $\$ 2,900$ is paid in electricity quality costs per unit, and $\$ 225$ is paid in system operation costs per unit. In addition to activity costs, it was assumed that externally, there were other abnormal operating costs of $\$ 820$ per unit related to operation of the turbine. It was also assumed that activity costs would increase at a rate of $1 \%$ per year.

Table 1: Input variables defined as assumptions for wind energy investment and assumptions for wind turbine WTG34

\begin{tabular}{|c|c|c|}
\hline \multicolumn{3}{|l|}{ ASSUMPTIONS } \\
\hline Production Parameters & Value & Unit \\
\hline Unit Number & 1 & \\
\hline Individual Unit Power & 3 & MW \\
\hline Electricity Selling Price & 0.073 & USD/kWh \\
\hline Domestic Incentives (Rotors and Nacelles) & 0.013 & $\mathrm{USD} / \mathrm{kWh}$ \\
\hline Domestic Incentives (Generators) & 0.01 & USD/kWh \\
\hline Domestic Incentives (Turbines) & 0.008 & USD/kWh \\
\hline Domestic Incentives (Turbine Towers) & 0.006 & USD/kWh \\
\hline \multicolumn{3}{|l|}{ Operating Costs } \\
\hline Maintenance and Repair Costs & 37,000 & USD /Unit \\
\hline Security Costs & 1,200 & $\begin{array}{l}\text { USD/Employed } \\
\text { Staff/Month }\end{array}$ \\
\hline Number of Security Staff & 0.25 & Employed Staff \\
\hline System Usage Costs & 35,000 & USD/Unit/Year \\
\hline Electricity Quality Cost & 2,900 & USD/Unit/Year \\
\hline System Operating Cost & 225 & USD/Unit/Year \\
\hline Other Operating Costs & 820 & USD/Unit/Year \\
\hline Rate of Increase of Actvity Costs & 1 & $\%$ \\
\hline \multicolumn{3}{|l|}{ Investment Expenditure } \\
\hline Turbine Cost & $1,100,000$ & USD/MW \\
\hline VAT for Turbine Purchase & 20 & $\%$ \\
\hline Turbine Switchyard Cost & 50,000 & USD/Unit \\
\hline Land Requirement (Nationalization) $\quad(*)$ & 10,000 & $\mathrm{~m}^{2} /$ Unit \\
\hline Land Use Cost $\quad(*)$ & 3,00 & $\mathrm{USD} / \mathrm{m}^{2}$ \\
\hline Turbine Access Road Cost & 100,000 & USD/Unit \\
\hline Project Development Cost & 25,000 & USD/MW \\
\hline Licence Fee & 10,000 & USD/MW \\
\hline Maintenance and Repair Equipment Cost & 30,000 & USD/Unit \\
\hline Other Costs & 10,000 & USD/Unit \\
\hline \multicolumn{3}{|l|}{ Financial Variables } \\
\hline Depreciation Rate & 0.5 & $\%$ \\
\hline Interest Rate & 7.5 & $\%$ \\
\hline Capital Ratio (Equity/ Total Sources) & 50 & $\%$ \\
\hline Working Capital Requirement & 100,000 & USD/Unit \\
\hline Depreciation Period & 25 & Year \\
\hline Inflation Rate - US Dollars & 1.5 & $\%$ \\
\hline VAT Rate & 18 & $\%$ \\
\hline Corporation Tax & 20 & $\%$ \\
\hline Equity Expectation Rate & 10 & $\%$ \\
\hline
\end{tabular}

The third group of input variables for wind turbine WTG34 is that of investment expenditure. Investment for WPP projects is the total expenditure made for installation of the turbine and completion of the electrical conduction until commencement of production. Within investment expenditure, the cost of the turbine was determined as $\$ 1,100,000$ per MW. In the ground works for the turbine installation site, the switchyard cost was assumed to be $\$ 50,000$ per unit turbine. The land use per turbine was $10,000 \mathrm{~m}^{2}$ and $\$ 3$ was paid per $\mathrm{m}^{2}$. For opening of the turbine access road, the cost was $\$ 100,000$ per turbine. In the pre-feasibility and project development period prior to making the WPP investment, $\$ 25,000$ was spent per MW production volume. When the project was begun, a $\$ 10,000$ licence fee was paid per MW. In addition to these, within the investment expenditure, it was assumed that $\$ 30,000$ per unit would be spent related to the purchase of repair and maintenance equipment. Finally, other costs per unit were assumed to be $\$ 10,000$.

The fourth group of input variables for wind turbine WTG34 is related to financing. It was assumed that there was an annual loss of capacity in the WPP 
investment compared to the previous year. As loss of capacity, the rate of wear and tear was selected as $0.5 \%$. In investment finance, there are choices of financing with debt or with equity. For financing with debt, the central bank's overnight borrowing rate was taken into account. For financing with debt, an annual rate of $7.5 \%$ was used as the input variable. Another resource cost is equity cost. Equity cost was taken to be approximately $10 \%$ per annum based on the Capital Asset Pricing Model. The working capital of the operation was assumed to be $\$ 100,000$ per unit. The depreciation period of the investment was assumed to be 25 years, and the depreciation of the investment was considered to be divided equally throughout its economic life. The annual dollar inflation rate was taken to be $2 \%$. The tax rates for the investment were taken as $18 \%$ for VAT and $20 \%$ for corporation tax.

The input variables defined as assumptions have been explained above. An input variable is defined as an independent variable that affects an investment at one point.

\section{Analysis findings}

Following the financial model created in this study, for the relocation of the turbine in the WPP investment to be profitable, the capacity factor of the new installation site of the turbine was determined. Wind turbine WTG34 was put into use and began production in 2012. In 2012 and 2013, production was carried out with capacity factors of $19 \%$ and $17 \%$ respectively. Following the year of its installation, if turbine WTG34 operates at a capacity of approximately $24 \%$ until the end of its economic life, the WPP investment project will have zero profit. If turbine WTG34 is not relocated, however, the probability of the investment producing a return within the 25 -year life of the turbine is low. In this case, the decision by the investor to install the turbine in a location where production can be made at a higher capacity is a logical one. From this viewpoint, even by adding the additional costs marked as (*) in Table 1 (turbine switchyard cost, land requirement, land use cost, turbine access road cost and project development cost), the turbine operating at a loss can become profitable. What is important here is the question of at least what capacity factor on average the new installation site of the turbine will work at until the end of its economic life.

As a result of the financial model created based on the input parameters included, when considering the investment payback period method, the results of the capacity factors required for the relocation to be significant are shown in Figure 4.

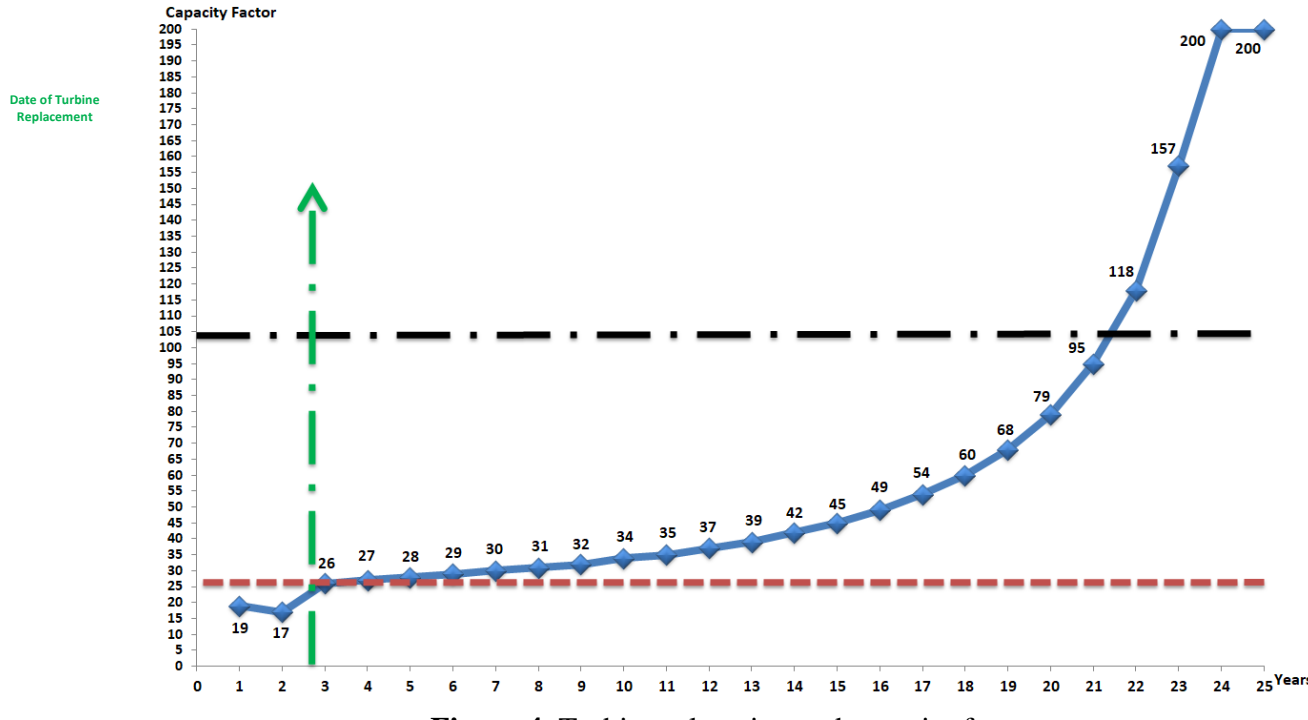

Figure 4. Turbine relocation and capacity factor.

Examining Figure 4, it can be seen that when the relocation of the WPP investment is made during the third year and if the capacity factor of the investment, which has an economic life of up to 25 years, at the new installation site is $26 \%$ and over after the third year, the relocation of the investment will be significant. If the capacity factor of the investment, which has an economic life of up to 25 years, at the new installation site is $27 \%$ and over after the fourth year, the relocation of the investment will be significant. For relocation in the following years to be significant, the minimum capacity factors are as follows: $28 \%$ and over in the 5 th year, $29 \%$ and over in the 6th year, $30 \%$ and over in the
7 th year, $31 \%$ and over in the 8th year, 32\% and over in the 9 th year, $34 \%$ and over in the 10th year, $35 \%$ and over in the 11th year, $37 \%$ and over in the 12th year, $39 \%$ and over in the 13 th year, $42 \%$ and over in the 14 th year, $45 \%$ and over in the 15 th year, $49 \%$ and over in the 16th year, $54 \%$ and over in the 17 th year, $60 \%$ and over in the 18th year, $68 \%$ and over in the 19th year, $79 \%$ and over in the 20th year, $95 \%$ and over in the $21 \mathrm{st}$ year, $118 \%$ and over in the 22 nd year, $157 \%$ and over in the 23rd year, and $200 \%$ in the 24th and 25 th years. Since there cannot be a capacity factor of over $100 \%$, relocation of the investment in the 22nd year or later is pointless (uneconomic). When the repair and 
maintenance of wind turbines is taken into consideration, it is natural for the optimum capacity factor to be below full capacity. The earlier the investment relocation is carried out, the lower the desired mean capacity factor will be until the end of the economic life of the investment. If the decision to relocate the investment is delayed, the desired capacity factor for the investment at its new installation site will increase for every year that it is delayed.

Similar results to those obtained for turbine WTG34 were determined for the other 7 turbines having low capacity factors.

\section{Conclusion and recommendations}

Dependence on energy is increasing day by day all over the world. Turkey, which is one of the developing countries, is the world's 17th largest and Europe's 6th largest economy. Together with its growing economy and increasing population, demand for energy in Turkey is rising rapidly. To meet this increasing energy need and to reduce foreign dependence on energy, the use of domestic and renewable energy sources must be increased. From this perspective, realistic targets for renewable energy sources should be set, and to reach these targets, the barriers preventing investments should be lifted.

When its potential for renewable energy sources is assessed, Turkey is a rich country. Another important matter that needs to be considered when making renewable energy investments is that of carrying out a technical analysis prior to making the investment and of installing the turbine in a location where maximum productivity can be obtained. Before companies make an investment in a renewable energy area, it is important that they undertake technical and economic feasibility studies of the investment. A pre-feasibility study will form a reference for the practicability of the investment. Following the pre-feasibility study, highproductivity renewable energy investments are important for providers of liability in terms of repayment of the credit they are to provide.

Following the financial model created in this study, for the relocation of the WTG34 turbine operating with a low capacity factor to be profitable, the capacity factor of the new installation site of the investment was determined. The results showed that it was important for the relocation decision to be made early for the investment to be more profitable. In the first two years of the turbine investment, the turbine operating at a low capacity of $19 \%$ and $17 \%$ is profitable if it works at $26 \%$ capacity until the end of its economic life when change is made in the third year. It is seen that the capacity factor increases for each year of delay for replacement. In the event of delayed decisions to relocate the turbine, a high capacity factor is expected in the new location. If a high capacity factor is not achieved, the relocation of the turbine will be meaningless and losses will be incurred for the investor.
When its potential for renewable energy sources is evaluated, Turkey is a rich country. When Turkey's future energy targets are examined, it is seen that a target for renewable energy sources to meet $30 \%$ of Turkey's energy consumption has been set for the year 2023.

Moreover, to reach the realistic targets determined for renewable energy, significant progress can be made by strengthening the incentive mechanism, making adjustments to periods and amounts in purchase guarantees, activating the operation of the Environmental Impact Assessment (EIA) and supporting technological developments related to renewable energy in domestic industry. Furthermore, informing entrepreneurs that plan to invest in this area about financial sources and access can make a positive contribution to speedier operation of the processes.

\section{References}

[1] Ministry of Energy and Natural Resources, https://enerji.gov.tr/, Accessed Date (11.10.2018).

[2] Develi, A. \& Kaynak, S. (2012). Energy Economics, Frankfurt am Main, ISBN 3631633335, DEU:Peter Lang AG.

[3] Turkish Wind Energy Association (2018), Turkish Wind Statistic Report, https://www.tureb.com. tr/yayinlar/turkiye-ruzgar-enerjisi-istatistik-raporutemmuz-2018

[4] Ministry of Energy and Natural Resources (2014). 2015-2019 Strategy Plan, http://sp.enerji.gov.tr/ ETKB_2015_2019_Stratejik_Plani.pdf.

[5] Bahgat, G. (2006). Europe's Energy Security: Challanges and Opportunities, International Affairs, 82(5): 961-975.

[6] Desrochers, G., Blanchard, M. \& Sud, S. (1986). A Monte-Carlo Simulation Method For The Economic Assessment of The Contribution of Wind Energy to Power Systems, IEEE Transactions on Energy Conversion, (4), 50-56.

[7] Venetsanos, K., Angelopoulou, P. \& Tsoutsos, T. (2002). Renewable Energy Sources Project Appraisal Under Uncertainty: The Case Of Wind Energy Exploitation Within A Changing Energy Market Environment. Energy Policy, 30(4), 293307.

[8] Liberman, E. J. (2003). A life cycle assessment and economic analysis of wind turbines using Monte Carlo simulation. MSc Thesis, Air Force Institute Of Technology, Wright-Patterson Air Force Base, Ohio.

[9] Özerdem, B., Ozer, S. \& Tosun, M. (2006). Feasibility study of wind farms: A case study for Izmir, Turkey, Journal of Wind Engineering and Industrial Aerodynamics, 94(10), 725-743.

[10] Vardar, A. \& Çetin, B. (2007). Cost Assessment of The Possibility of Using Three Types of Wind Turbine in Turkey. Energy Exploration \& 
Exploitation, 25(1), 71-82.

[11] Moran, D. \& Sherrington, C. (2007). An Economic Assessment of Windfarm Power Generation in Scotland Including Externalities, Energy Policy, 35(5), 2811-2825.

[12] Madlener, R., \& Wenk, C. (2008). Efficient investment portfolios for the Swiss electricity supply sector.

[13] Williams, S. K., Acker, T., Goldberg, M. \& Greve, M. (2008). Estimating the economic benefits of wind energy projects using Monte Carlo simulation with economic input/output analysis. Wind Energy, 11(4), 397-414.

[14] Vardar, A. \& Çetin, B. (2009). Economic Assessment of The Possibility of Using Different Types of Wind Turbine in Turkey, Energy Sources, Part B, 4(2), 190-198.

[15] Ay, A. (2010). Energy Sources And Investment Project Assessment: A Case Study About Wind Energy In Turkey, Masters Thesis, Bahçeşehir University, Istanbul.

[16] Hamamcioğlu, V. (2010). Rüzgar Enerji Kaynakl Elektrik Üretiminin Teknik/Ekonomik Analizi ve Yöresel Uygulaması, Masters Thesis, Yıldız Teknik Universitesi, Istanbul.

[17] Frølunde, S. G., \& Obling, P. E. (2010). Valuation models for wind farms under development. Graduate Thesis, http://studenttheses.cbs.dk/handle/10417/1080.

[18] Cardell, J. B. \& Anderson, C. L. (2010). Analysis of The System Costs of Wind Variability Through Monte Carlo Simulation, In System Sciences (HICSS), 43rd Hawaii International Conference on System Sciences, 1-8.

[19] Rehman, S., Ahmad, A. \& Al-Hadhrami, L. M. (2011). Development and Economic Assessment of a Grid Connected 20 MW Installed Capacity Wind Farm, Renewable and Sustainable Energy Reviews, 15(1), 833-838.

[20] Ertürk, M. (2012). The Evaluation of Feed-In-Tariff Regulation of Turkey For Onshore Wind Energy Based on The Economic Analysis, Energy Policy, 45, 359-367.
[21] Doğan, B. T., Çolakoğlu, A. \& Kincay, O. (2012). RETScreen Analiz Programı ile Hatay'da Rüzgar Enerji Santrali Fizibilite Analizi, Tesisat Mühendisliği, 131, 22-27.

[22] Khindanova, I. (2013). A Monte Carlo Model of a Wind Power Generation Investment, The Journal of Applied Business and Economics, 15(1), 94.

[23] Özçelik, B. D. (2016). Türkiye'de Rüzgar Enerjisinin Durumu: Karaburun, Urla, Samandağ ve Hereke Rüzgar Enerjisi Santralleri Fizibilite Analizi, Maliye Finans Yazıları, (106), 49-72

[24] Simoes, M. G. \& Farret, F. A. (2008). Alternative Energy Systems Design and Analysis With Induction Generators, CRC Press, Second Edition, ISBN. 9781-4200-5532-0, USA

[25] Ross, S, Westerfield, R. W. \& Jaffe, J. (2010). Corporate Finance, Ninth Edition, McGrawHill.

[26] Manwell, J.F., Mcgowan J.G. \& Roger, A.L. (2010).Wind Energy Explained: Theory, Design and Application, Second Edition, John Wiley \& Sons Ltd.

[27] Durak, M. \& Özer, S. (2008). Rüzgar Enerjisi Teori ve Uygulama, Ankara.

[28] Tansi, B.N. (2012). An Assessment of Cameroons Wind and Solar Energy Potential - A Guide for A Sustainable Economic Development, Hamburg, DEU: Diplomica Verlag.

Hasan Huseyin Yildirim received his Master's Degree (2011) in Finance from Marmara University and obtained a PhD Degree (2016) from Istanbul University. Mr. Yildirim is Assist. Prof. in the Burhaniye School of Applied Sciences at Balikesir University. His research interests include the economy, finance and banking sector and renewable energy investments.

Sakir Sakarya received his Master's Degree (1994) in Business and obtained a PhD Degree (2002) from Sakarya University in Turkey. Currently, Mr. Sakarya is a Professor in the Faculty of Economics and Administrative Sciences at Balikesir University. Mr. Sakarya has extensive experience in the finance and investment sector. His main research interest is financial management.

An International Journal of Optimization and Control: Theories \& Applications (http://ijocta.balikesir.edu.tr)

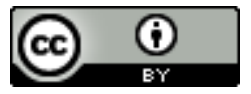

This work is licensed under a Creative Commons Attribution 4.0 International License. The authors retain ownership of the copyright for their article, but they allow anyone to download, reuse, reprint, modify, distribute, and/or copy articles in IJOCTA, so long as the original authors and source are credited. To see the complete license contents, please visit http://creativecommons.org/licenses/by/4.0/. 